\title{
Recovery and Purification of Tin from Tailings from the Penouta Sn-Ta-Nb Deposit
}

\author{
Félix Antonio López ${ }^{1, *}$ (D), Irene García-Díaz ${ }^{1}$, Olga Rodríguez Largo ${ }^{1}$, \\ Francisco García Polonio ${ }^{2}$ and Teresa Llorens ${ }^{2}$ \\ 1 National Center for Metallurgical Research (CENIM), CSIC, 28040 Madrid, Spain; \\ irenegd@cenim.csic.es (I.G.-D.); olgarodriguez@cenim.csic.es (O.R.L.) \\ 2 Strategic Minerals Spain S.L., 32558 Penouta, Spain; fpolonio@strategicminerals.com (F.G.P.); \\ tllorens@strategicminerals.com (T.L.) \\ * Correspondence: f.lopez@csic.es; Tel.: +34-915-538-900
}

Received: 17 November 2017; Accepted: 8 January 2018; Published: 12 January 2018

\begin{abstract}
A concentrate obtained from mining tailings containing mainly cassiterite and columbotantalite was reduced for the production of tin metal. The compounds $\mathrm{CaCO}_{3}, \mathrm{Na}_{2} \mathrm{CO}_{3}, \mathrm{~K}_{2} \mathrm{CO}_{3}$, and borax were used as fluxes in the pyrometallurgical reduction smelting process, and graphite was employed as the reducing agent. The greatest recovery of $\mathrm{Sn}(>95 \%)$ was obtained when using $\mathrm{CaCO}_{3}$ as the flux; the purity of Sn was $96 \%$. A slag equivalent to $25 \%$ of the mass of the initial concentrate was produced during the recovery of the $\mathrm{Sn}$. This contained $45 \% \mathrm{Nb}_{2} \mathrm{O}_{5}$ and $\mathrm{Ta}_{2} \mathrm{O}_{5}$, adding extra value to the mine tailings. The tin metal ingot was purified by electrorefining involving a tin and $\mathrm{H}_{2} \mathrm{SO}_{4}$ electrolyte solution and a $101.9 \mathrm{~A} / \mathrm{m}^{2}$ current applied for $148 \mathrm{~h}$. Under these conditions, $90 \mathrm{wt} \%$ of the $\mathrm{Sn}$ in the ingot was recovered at a purity of $99.97 \%$.
\end{abstract}

Keywords: cassiterite; columbotantalite; pyrometallurgical reduction smelting process; tin; electrorefining; calcium-niobium-tantalum oxides

\section{Introduction}

The malleability, ductility, and resistance to corrosion of tin render it suitable for use in a variety of applications. Tin is produced in almost equal amounts from ores (mostly conventionally mined but also via some artisanal mining) and secondary sources (recycled materials), both yielding some 300,000 tons per year [1]. The most important tin mineral is cassiterite $\left(\mathrm{SnO}_{2}\right)$, which is commonly concentrated by gravity separation methods owing to the differences between the density of the materials in the gangue (usually silicates) [2], and flotation techniques [3-5]. China and Indonesia together produce about $70 \%$ of the world's tin, and it is in these countries where most of the world's tin smelters are located. Tin recycling, however, is an industry unlikely to wane in importance since about $30 \%$ of all the tin produced goes into recyclable tin-lead alloys, solder, brass, and bronze. The tin extracted from them requires no new refining [1].

The demand for tin has been increasing for the last 30 years and is expected to grow by $2 \%$ per annum over the next 5-10 years [1]. A secure supply is essential for the construction business, the manufacture of vehicles, other consumer goods, and even packaging. One of its most important uses is in the manufacture of specialized solders for the electronics industry. It is also required for novel applications such as new lithium ion batteries, tin-stainless steel alloys, and energy production technologies. It is therefore important that new techniques for obtaining tin be investigated. Those that could valorize abandoned mining residues would be of particular interest.

The fall in the price of metals during the 1980s led to the closure of many tin mines. Many of these were located in Europe's Variscan Belt, whichk has both $\mathrm{Sn}-\mathrm{W}$ and $\mathrm{Sn}-\mathrm{Nb}-\mathrm{Ta}$ deposits. Unfortunately, these are not always very rich, making their exploitation unprofitable. The fusion and electrorefining 
techniques discussed in the present work, however, could change this, allowing, for example, the Golpejas and Penouta [6] mines in Spain to be re-opened. It could also make the mining of the Cínovec granitic cupula in the Moldanubian Zone of the Czech Republic [7] viable (the area is currently being surveyed) and help bring the Beauvoir Granite of the Massif Central in France $[8,9]$ into production.

The Penouta Sn-Ta-Nb deposit is located in the Central Iberian Zone (CIZ) towards the innermost part of the Iberian Variscan Belt in Galicia, northwestern Spain. Here, the Viana do Bolo Series (which consists mainly of highly metamorphic rocks) and the Ollo de Sapo Formation (best represented in this zone by an augen gneiss) crop out. The deposit is largely a sheet-like albitized and greisenized granitic cupola, elongated in the SW-NE direction, with a maximum length of about $1100 \mathrm{~m}$, a maximum E-W width of $700 \mathrm{~m}$, and a maximum depth of over $200 \mathrm{~m}$ [10]. It is mainly composed of quartz, albite, muscovite and K-feldspar, with garnet and beryl as common accessory minerals. Banded pegmo-aplite dikes commonly occur in the apical zone of the granite. The cupola system culminates with the development of a stockwork of quartz veins up to $2 \mathrm{~m}$ thick, which caused the strong greisenization of the hosting augen gneiss and the granitic cupola. The deposit was extensively mined during the 1970s to obtain cassiterite from the latter cupola and the related hydrothermal quartz veins. Tantalum was obtained as a by-product. The open pit methods employed targeted the kaolinized leucogranite and those portions of the host rock that had become muscovitized and soft enough to be extracted using free-dig methods. These materials were not milled, and only fragments up to $2 \mathrm{~mm}$ in size were treated in the gravity plant. Thus, large amounts of cassiterite and columbite group minerals were never liberated from the unused host rock, which was progressively dumped in tailing ponds [6]. Strategic Minerals Spain S.L. (Penouta, Spain), which owns the exploitation rights to the Penouta Mine, has recently constructed a gravimetric separation plant for the processing of these wastes. Designed to handle 1 million tons per annum, the plant possesses a series of milling, cyclonic separation, gravimetric concentration (via spirals and shaking tables) and magnetic separation facilities that allow a concentrated $\mathrm{Sn}-\mathrm{Nb}$-Ta mineral to be obtained. Given the very different prices they demand, $\mathrm{Sn}$ and $\mathrm{Ta}-\mathrm{Nb}$ concentrates are normally marketed separately. However, the small grain size of the $\mathrm{Ta}-\mathrm{Nb}$ minerals at the Penouta Mine, and their strong relationship with cassiterite, make it hard to obtain separate concentrates; new methods that can separate the $\mathrm{Sn}$ and $\mathrm{Nb}$ - $\mathrm{Ta}$ are therefore required. The present work investigates the use of carbothermic reduction smelting and electrorefining.

Carbothermic reduction smelting [11] is a very effective way of obtaining Sn from gangue minerals. Different authors have examined the reduction of cassiterite using methane [12,13], carbonaceous reductants [12,14] and direct reduction [15]. $\mathrm{SnO}_{2}$ is mainly reduced by the gaseous intermediates of $\mathrm{CO}$ and $\mathrm{H}_{2}$, and the overall reduction rate of $\mathrm{SnO}_{2}$ controlled by the gasification of carbon $\left(\mathrm{C}+\mathrm{CO}_{2} \rightarrow \mathrm{CO}\right.$, Boudouard reaction). Some admixtures, e.g., $\mathrm{K}_{2} \mathrm{CO}_{3}, \mathrm{SiO}_{2}, \mathrm{Al}_{2} \mathrm{O}_{3}, \mathrm{CaO}$ or metallic $\mathrm{Sn}$, accelerate the reduction of cassiterite by graphite $[16,17]$. All of these admixtures reduce the activation energy required for the reduction reaction to occur, i.e., they have catalytic effects on the Boudouard reaction [14].

Electrorefining can be used to extract $\mathrm{Sn}$ in ultrapure form (without Fe) from ingots: metallic $\mathrm{Sn}$ appears at the cathode, while any Fe present accumulates at the anode in sludge form (the electrochemical potential of the $\mathrm{Sn} / \mathrm{Sn}^{2+}$ system is $-0.14 \mathrm{~V}$ while that of the $\mathrm{Fe} / \mathrm{Fe}^{+2}$ system is $0.44 \mathrm{~V}$ ). Rimaszeki et al. $[18,19]$ described the recovery of metallic Sn from waste solder via electrorefining using $\mathrm{HCl}$ as an electrolyte. Kékesi [20] successfully recovered Sn from waste solder using $\mathrm{HCl}$ and $\mathrm{SnCl}_{2}$ as electrolytes.

The present work examines the pyrometallurgical reduction smelting of the Penouta Mine's residues for the production of metallic tin, and the purification (removal of Fe impurities) of the latter by electrorefining. 


\section{Materials and Methods}

A mineral concentrate obtained by the milling, gravimetric concentration, and magnetic separation of mining tailings containing mainly cassiterite was used as a source material for the production of metallic tin. The tailings, which came from the Penouta Mine, were provided by Strategic Minerals S.L.

$\mathrm{An} \mathrm{Sn}-\mathrm{Nb}$-Ta concentrate was obtained from these tailings by gravimetric separation at the on-site plant owned by the company. This process involves the following:

1. Milling. The tailings are milled in a mineral ball mill to a particle size of approximately $300 \mu \mathrm{m}$.

2. Cyclonic separation. Very small-grained material $(<75 \mu \mathrm{m})$ is removed; the remaining material is retained for gravimetric concentration.

3. Gravimetric concentration. This involves several stages of gravity-assisted concentration made possible by density differences:

a. Spirals. Rougher, cleaner, recleaner and scavenger spirals remove the sterile material of lower density (gangue minerals such as silicates), concentrating the those of interest. The product then passes to the next stage.

b. Shaking tables. Rougher, cleaner, recleaner and scavenger stage shaking tables separate the minerals on the basis of their density. The product then passes to the next stage.

c. Falcon treatment. Gravimetric concentration, using centripetal force for the concentration of the finest metallic particles.

4. Low-intensity magnetic separation. This separates out the non-mineralogical iron (not associated with columbo-tantalite) as well as that released during milling. The aim is to improve the purity of the $\mathrm{Sn}$ to be obtained in later processing.

5. Drying. The gravimetric concentration process occurs under $30 \% / 70 \%$ solid/liquid conditions. The resulting materials must, therefore, be dried before further processing.

Figure 1 provides a view of some parts of the plant where the $\mathrm{Sn}-\mathrm{Nb}-\mathrm{Ta}$ concentrate is obtained.

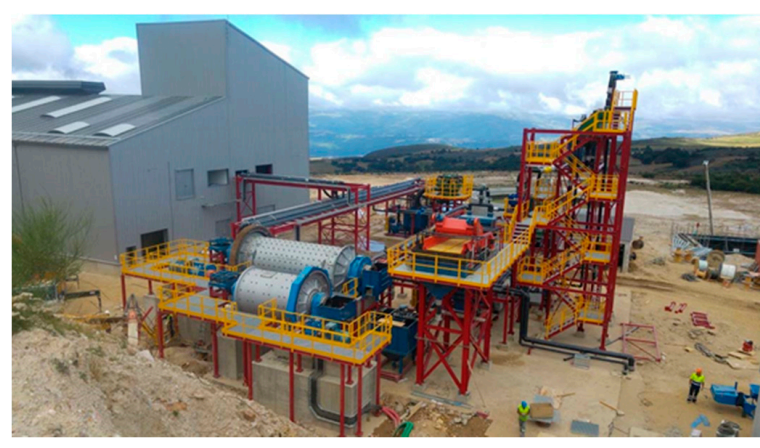

(a)

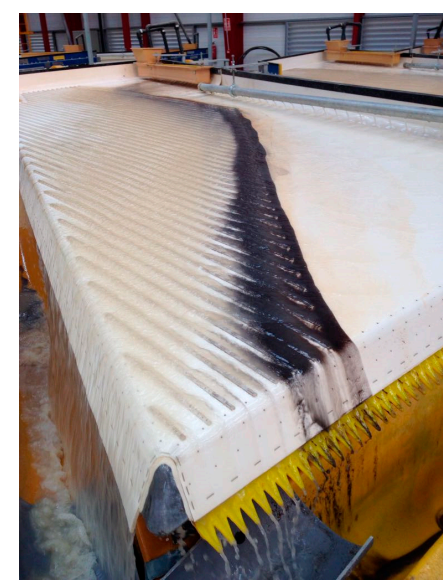

(b)

Figure 1. Milling facility (a) and shaking table (b) for concentrating the $\mathrm{Sn}-\mathrm{Nb}-\mathrm{Ta}$ mineral.

The distribution of the particle size was determined by diffraction using a Malvern Mastersizer $S$ device (Malvern, Worcestershire, UK) equipped with a He-Ne laser $(\lambda=632.8 \mathrm{~nm})$, employing dampened samples (dispersed in water containing an anti-flocculant in an ultrasonic bath). The concentrate produced was analyzed by X-ray fluorescence spectroscopy (XRF) using a Bruker S8 Tiger (Bruker, Billerica, MA, USA) device, and by atomic absorption (AA) using a SpectrAA 220 FS AA spectrometer (Varian, Palo Alto, CA, USA). The phase compositions were characterized by X-ray diffraction analysis (XRD) using a Siemens D5000 (Siemens, Berlin, German) apparatus and quantified 
by the Rietveld method. The concentrate was also subjected to morphological examination by field emission scanning electron microscopy (FE-SEM) using a JEOL JSM 6500 microscope (Jeol, Tokyo, Japan) equipped with an Oxford EDX energy-dispersive X-ray (EDX) analyzer for semi-quantifying the elemental composition (FE-SEM-EDX).

Metallic tin was obtained from the concentrate (held in graphite crucibles) via pyrometallurgical reduction smelting at $1100-1200{ }^{\circ} \mathrm{C}$ in an AFI-02 induction furnace containing an argon atmosphere. Different blends of graphite (Desulco ${ }^{\circledR}$ 9012S, 99.9\% C, 0.041\% S, 42 ppm N and 10 ppm H) and fluxes were tested (Table 1 ) as a means of reducing the melting point and to increase the $\mathrm{Nb}$ and Ta content of the slag produced. The furnace temperature was raised to $1200{ }^{\circ} \mathrm{C}$. The $\mathrm{Sn}$ samples obtained were subjected to optical emission spectrometry (OES) using a Varian ICP-OES 725-ES (Varian, Palo Alto, CA, USA) instrument; all were attacked with lithium metaborate at $1050{ }^{\circ} \mathrm{C}$ and acidified with $\mathrm{HNO}_{3}$ before taking readings. The slag produced during the processing of the concentrate was characterized by electron microprobe microscopy (EMP) using a JEOL JEM 2100 microprobe (Jeol, Tokyo, Japan).

Table 1. Blends used in the pyrometallurgical reduction smelting process.

\begin{tabular}{|c|c|c|c|}
\hline$\%$ (Weight) & Blend A & Blend B & Blend C \\
\hline Concentrate & 85.5 & 80.0 & 74.6 \\
\hline $\mathrm{CaCO}_{3}$ & 8.6 & - & 7.5 \\
\hline Borax & - & 5.5 & - \\
\hline $\mathrm{Na}_{2} \mathrm{CO}_{3}$ & - & 6.5 & 7.5 \\
\hline $\mathrm{K}_{2} \mathrm{CO}_{3}$ & - & - & 5.2 \\
\hline Graphite & 6.0 & 8.0 & 5.2 \\
\hline $\mathrm{C} / \mathrm{SnO}_{2}$ (mol ratio) & $1 / 0.76$ & $1 / 0.54$ & $1 / 1.16$ \\
\hline
\end{tabular}

The metallic tin obtained by the pyrometallurgical reduction process was then melted and an ingot prepared (dimensions $18 \mathrm{~cm} \times 10 \mathrm{~cm} \times 0.6 \mathrm{~cm}$, mass $0.688 \mathrm{~kg}$ ) for use as an anode to allow its purification by electrorefining. Electrorefining was performed using a $5.3 \mathrm{~L}$ capacity electrolytic cell, into which two Sn cathodes (dimensions $15 \mathrm{~cm} \times 11 \mathrm{~cm} \times 0.1 \mathrm{~cm}$, mass $200 \mathrm{~g}$ ) and the prepared anode were inserted (order: cathode-anode-cathode) [21]. All electrodes were submerged in an electrolyte pumped continuously through the cell. The electrical current was supplied using a 32 V, 6A LNG 32-6 Heinzinger power supply. A Graphtec model GL220 MIDI Logger (Graphtec, Tokyo, Japan) was used to monitor the current. The cell voltage $\left(V_{c}\right)$ was $0.5 \mathrm{~V}$ (calculated as the mean tension between the anode and cathode of the generator over time $(t(\mathrm{~h})$ of operation, at a current $I)$. The electrolyte was prepared by dissolving $250 \mathrm{~g}$ Sn granules in $1 \mathrm{~L}$ of $18 \mathrm{M} \mathrm{H}_{2} \mathrm{SO}_{4}$ for $72 \mathrm{~h}$ with agitation. The resulting solution was filtered to remove any unwanted, presumably hydrated oxide-type precipitate. An aliquot of the filtrate was diluted with distilled water to obtain a concentration equivalent to $0.85 \mathrm{M} \mathrm{H}_{2} \mathrm{SO}_{4}$, containing $215 \pm 6 \mathrm{mg} / \mathrm{L}$ Sn. This value was confirmed using a Perkin Elmer OPTIMA 3300 DV (Perkin, Waltham, MA, USA) optical emission spectrometer (OES) with an inductively coupled plasma (ICP) excitation source. Analytical grade thiourea (1 g/L) (Sigma-Aldrich, St. Louis, MO, USA) was added to the electrolyte to inhibit dendritic Sn crystal growth at the cathode. Table 2 summarizes the electrorefining conditions used.

Table 2. Electrorefining conditions.

\begin{tabular}{cccc}
\hline Current (A) & Electrolyte Flow Rate (L/h) & Anode-Cathode Separation (cm) & Reaction Time (h) \\
\hline 1.20 & 5 & 4 & 148 \\
$\left(190.1 \mathrm{~A} / \mathrm{m}^{2}\right)$ & & & \\
\hline
\end{tabular}

The purified Sn deposits produced in the different tests were characterized by washing with distilled water, drying at $80{ }^{\circ} \mathrm{C}$ in an oven, and then melting at $1150{ }^{\circ} \mathrm{C}$ in a graphite crucible in an inert atmosphere inside a Morgan-type oven. The melted mass was poured into a mold to produce 
metallic bars of dimensions $60 \mathrm{~mm} \times 26 \mathrm{~mm} \times 10 \mathrm{~mm}$ for analysis. The chemical composition of these bars was determined using a Spectromax spark optical emission spectrometer (Spectromax, Surrey, UK). After each electrorefining process, the sludge deposited on the anode was washed with distilled water, dried at $80^{\circ} \mathrm{C}$, and weighed. Its chemical composition was then determined using a Varian SpectrAA 220 FS atomic absorption spectrometer (Varian, Palo Alto, CA, USA) equipped with a hydride generator. Figure 2 shows a diagram of the entire process followed.

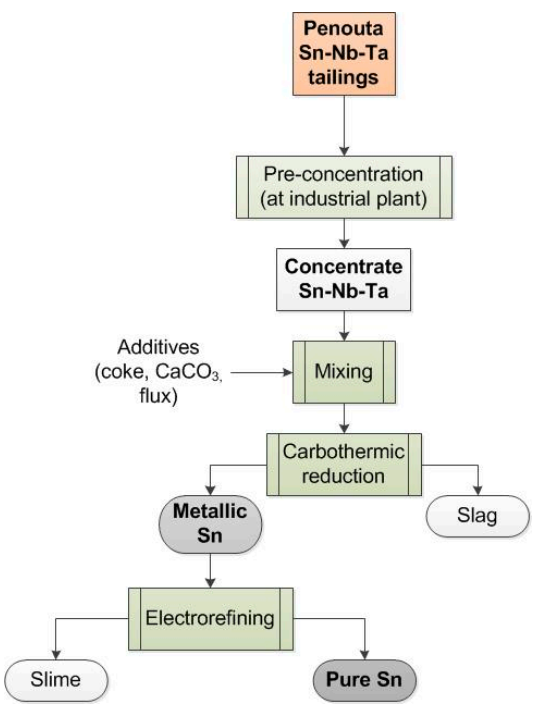

Figure 2. Process followed from tailings to recovery of pure Sn.

\section{Results}

\subsection{Chemical and Mineralogical Characterization of the Concentrate}

The concentrate was composed of $\mathrm{SnO}_{2}$ (67.20 wt \%), $\mathrm{Ta}_{2} \mathrm{O}_{5}$ (8.45 wt \%), $\mathrm{Fe}_{2} \mathrm{O}_{3}$ (6.99 wt \%) and $\mathrm{Nb}_{2} \mathrm{O}_{5}(5.40 \mathrm{wt} \%)$. The Rietveld-quantified majority phase was cassiterite $\left(\mathrm{SnO}_{2}\right)$ $(64.4 \%)$, followed by columbotantalite $\left((\mathrm{Fe}, \mathrm{Mn})(\mathrm{Ta}, \mathrm{Nb})_{2} \mathrm{O}_{6}\right)(21.5 \%)$, and different phases containing $\mathrm{Nb}$ and $\mathrm{Ta}$, such as ixiolite $\left((\mathrm{Sn}, \mathrm{Fe})(\mathrm{Sn}, \mathrm{Ta}, \mathrm{Nb})_{2} \mathrm{O}_{6}\right)$, and finally quartz $\left(\mathrm{SiO}_{2}\right)$ (Figure 3). Figure 4 shows the mineralogical characteristics of the concentrate as determined by FE-SEM-EDX (Field Emission-Scanning Electron Microscopy-Energy Dispersive X-Ray). Large grains of cassiterite $\left(\mathrm{SnO}_{2}\right)$ were seen, along with mixed grains of cassiterite-silico aluminates, $\mathrm{Sn}$-Ta oxides, columbotantalite, quartz and zirconium oxide. The particle size distribution was: $\mathrm{D}_{10}=0.61 \mu \mathrm{m} ; \mathrm{D}_{50}=9.85 \mu \mathrm{m}$ and $\mathrm{D}_{90}=10.44 \mu \mathrm{m}$.

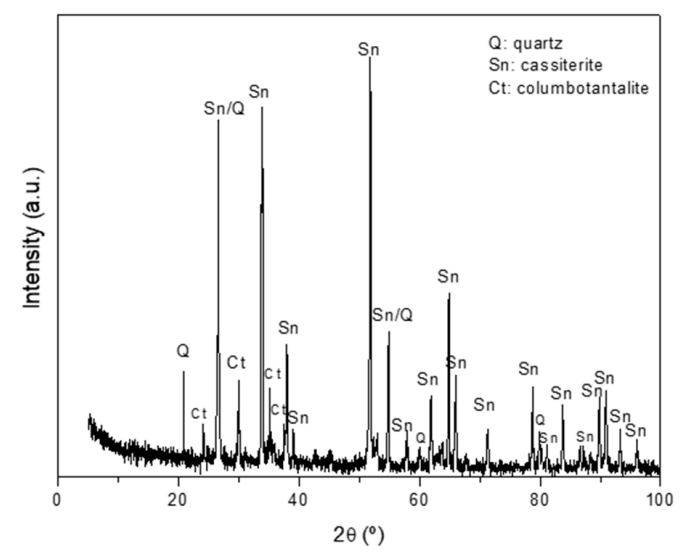

Figure 3. X-ray diffraction analysis (XRD) patterns of the mineral concentrate. 

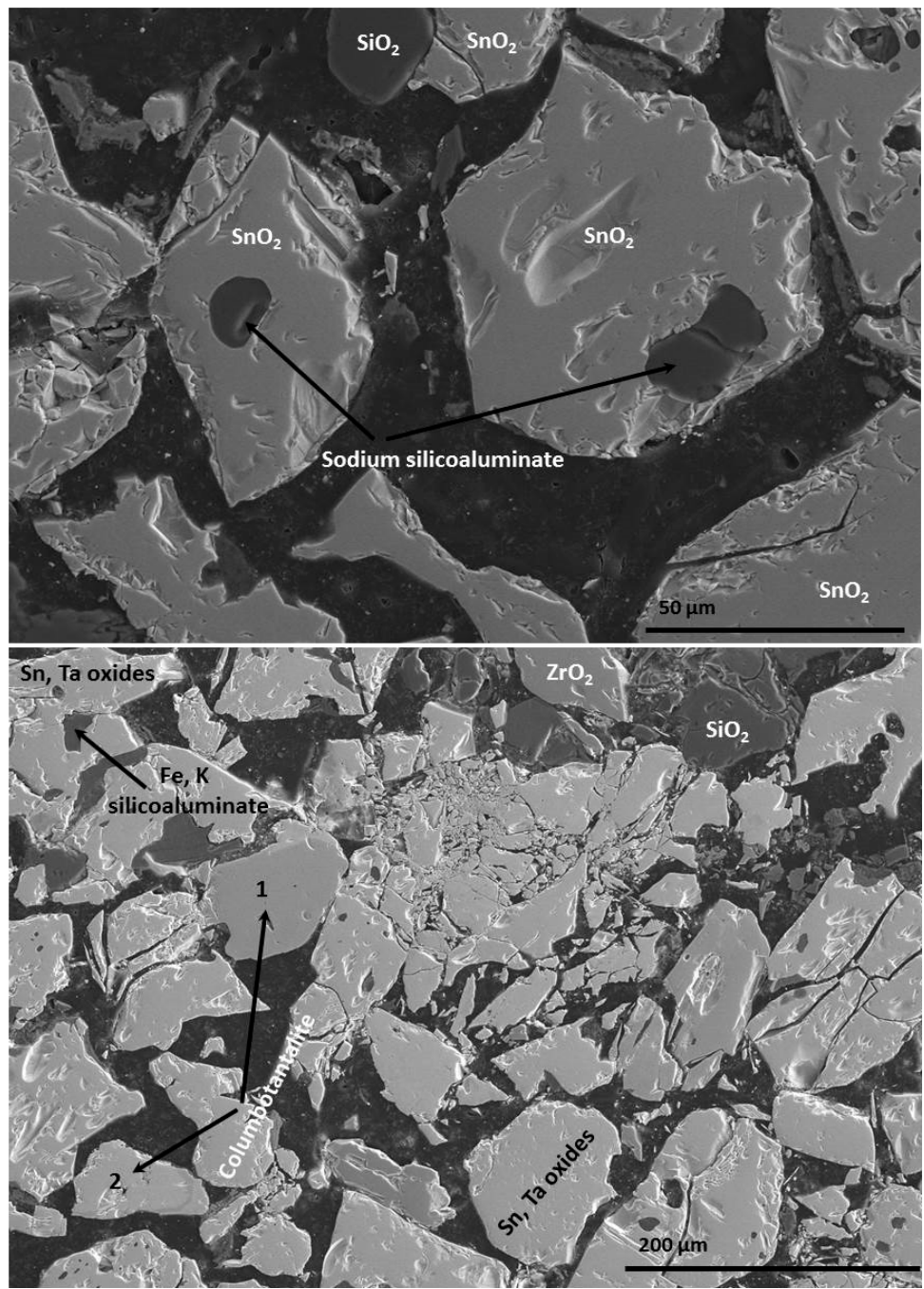

Figure 4. FE-SEM-EDX EDX (Field Emission-Scanning Electron Microscopy-Energy Dispersive X-Ray) images of the mineral concentrate.

\subsection{Obtaining Sn from the Mineral Concentrate}

The greatest recovery of $\mathrm{Sn}(>95 \%)$ was obtained when using $\mathrm{CaCO}_{3}$ (blend A; Table 3). The OES analysis returned a percentage purity of $96 \%$ (Table 4), similar to that obtained with ores and other industrial wastes. However, the recovered metallic Sn had an Fe content of $>3 \%$; any Sn recovered by this method, therefore, requires purification. The presence of $\mathrm{Fe}$ is the consequence of its intrinsic presence in Penouta cassiterite. Given the relationship between the ionic radius and electronegativity, the isomorphic substitution between $\mathrm{Sn}^{2+} / \mathrm{Fe}^{2+}$ and $\mathrm{Sn}^{4+} / \mathrm{Fe}^{3+}$ occurs easily [22].

Table 3. Tin recovery via the pyrometallurgical reduction smelting process depending on the type of mixture used.

\begin{tabular}{cc}
\hline Blend & Sn Recovery (wt \%) \\
\hline Blend A & $95.2 \pm 3.8$ \\
Blend B & $87.6 \pm 0.6$ \\
Blend C & $54.0 \pm 0.3$ \\
\hline
\end{tabular}


Table 4. Chemical composition of tin metal obtained by the pyrometallurgical reduction smelting process.

\begin{tabular}{cc}
\hline Element & Content \\
\hline $\mathrm{Sn}$ & $96.06 \mathrm{wt} \%$ \\
$\mathrm{Fe}$ & $3.46 \mathrm{wt} \%$ \\
$\mathrm{Mn}$ & $0.19 \mathrm{wt} \%$ \\
$\mathrm{Nb}$ & $998 \mathrm{ppm}$ \\
$\mathrm{Cr}$ & $899 \mathrm{ppm}$ \\
$\mathrm{Ti}$ & $385 \mathrm{ppm}$ \\
$\mathrm{Cu}$ & $276 \mathrm{ppm}$ \\
\hline
\end{tabular}

\subsection{Electrorefining}

Figure 5a shows the electrorefining cell and the cathodes with their Sn deposits. Figure 5b shows one of these cathodes on which the $\mathrm{Sn}$ deposit has taken the form of aciculate crystals. The quantity of Sn deposited was $2.5 \mathrm{~g} / \mathrm{h}$; the quantity of slime formed at the anode was $28 \mathrm{~g} / \mathrm{kg} \mathrm{Sn}$. After $148 \mathrm{~h}$ of reaction, the Sn deposit had the chemical composition shown in Table 5; the same table shows the composition of the slime. The Sn obtained was very pure (99.97\%); virtually all the Fe had been eliminated. The yield of purified $\mathrm{Sn}$ was $90 \%$ with respect to the $\mathrm{Sn}$ anode produced via carbothermic reduction. Figure 6 shows the highly pure Sn finally obtained.

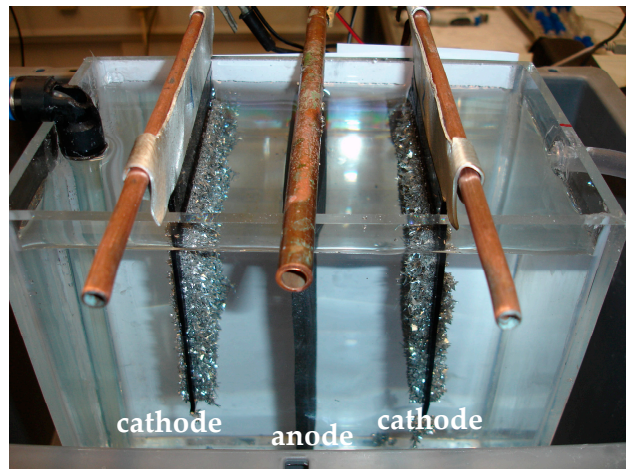

(a)

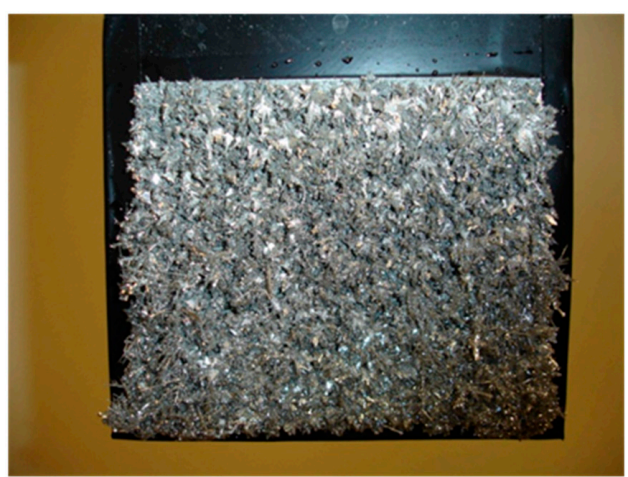

(b)

Figure 5. Electrolytic cell (a) and cathode (Sn deposit) (b).

Table 5. Chemical composition (mass \%) of the Sn deposited, and of the slime.

\begin{tabular}{cccccc}
\hline Metal & Sn & Fe & Ag & Cu & Pb \\
\hline Pure Sn & 99.97 & 0.005 & 0.007 & 0.010 & 0.009 \\
Anode Slime & 53.28 & 0.44 & 0.16 & 44.49 & 1.63 \\
\hline
\end{tabular}

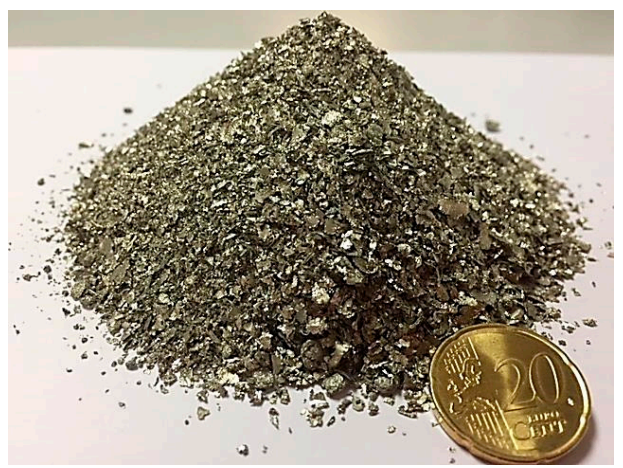

Figure 6. Highly pure Sn obtained by electrorefining. 
3.4. Characterization of the Slag Produced by the Pyrometallurgical Reduction Smelting Process

The mass of the slag obtained during the recovery of the Sn was equivalent to $25 \%$ of the mass of the initial concentrate. This easily ground, glassy material was characterized by XRF (Table 6). Its $\mathrm{Nb}_{2} \mathrm{O}_{5}$ and $\mathrm{Ta}_{2} \mathrm{O}_{5}$ contents reached $46 \%$ each. Mineralogically it contained $\mathrm{Ca}-\mathrm{Nb}-\mathrm{Ta}$ oxides of different stoichiometry $\left(\mathrm{Ca}_{2}(\mathrm{Nb}, \mathrm{Ta})_{2} \mathrm{O}_{7}\right.$ and $\left.\mathrm{Ca}(\mathrm{Nb}, \mathrm{Ta}) \mathrm{O}_{3}\right)$, plus much smaller proportions of other oxides of $\mathrm{Nb}$, Ta, $\mathrm{Mn}$ and $\mathrm{Fe}\left((\mathrm{Fe}, \mathrm{Mn})_{2}(\mathrm{Nb}, \mathrm{Ta})_{2} \mathrm{O}_{6}\right)$. Figure 7 shows the proportions recorded by the Rietveld method.

Table 6. Chemical composition of the slag (expressed at wt \% of oxides).

\begin{tabular}{cc}
\hline Component & Content (wt \%) \\
\hline $\mathrm{Ta}_{2} \mathrm{O}_{5}$ & 25.48 \\
$\mathrm{Nb}_{2} \mathrm{O}_{5}$ & 21.43 \\
$\mathrm{CaO}$ & 15.79 \\
$\mathrm{SiO}_{2}$ & 10.00 \\
$\mathrm{MnO}$ & 7.23 \\
$\mathrm{SnO}_{2}$ & 5.66 \\
$\mathrm{ZrO}_{2}$ & 3.68 \\
$\mathrm{Al}_{2} \mathrm{O}_{3}$ & 3.23 \\
$\mathrm{Fe}_{2} \mathrm{O}_{3}$ & 0.73 \\
$\mathrm{TiO}_{2}$ & 0.62 \\
$\mathrm{~K}_{2} \mathrm{O}$ & 0.51 \\
$\mathrm{Na}_{2} \mathrm{O}$ & 0.30 \\
$\mathrm{MgO}$ & 0.14 \\
\hline
\end{tabular}
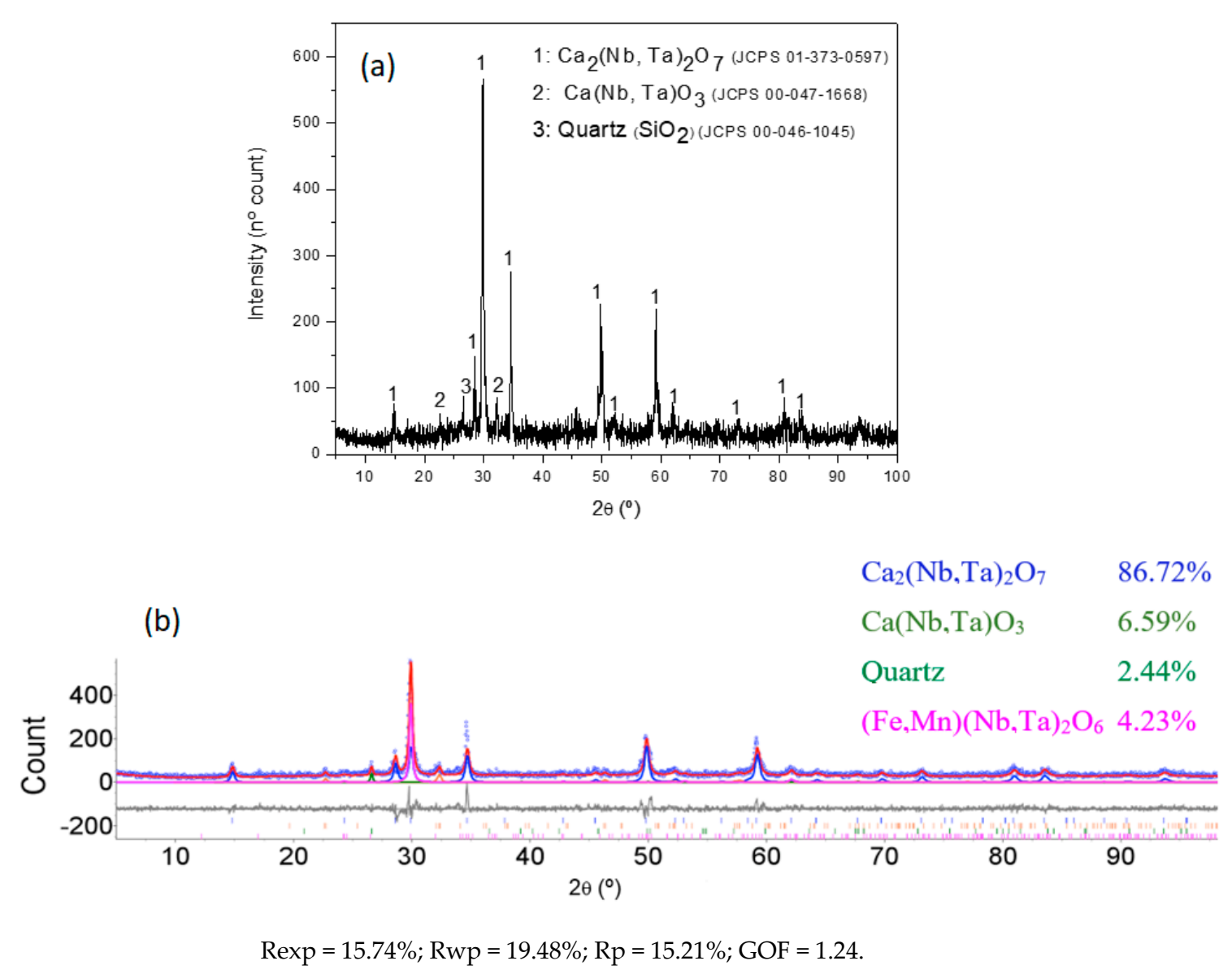

Figure 7. XRD pattern (a) and Rietveld fit for the X-ray diffractogram of the slag (b). 
The slag was also characterized by EMP (Figure 8), which underscored the presence of mixed oxides of $\mathrm{Nb}-\mathrm{Ta}-\mathrm{Ca}$, confirming the results obtained by XRD. Since oxides of $\mathrm{Nb}$ and $\mathrm{Ta}$ also concentrated in the slag, these metals might also be recovered, investing the tailings of the Penouta mine with further added value.

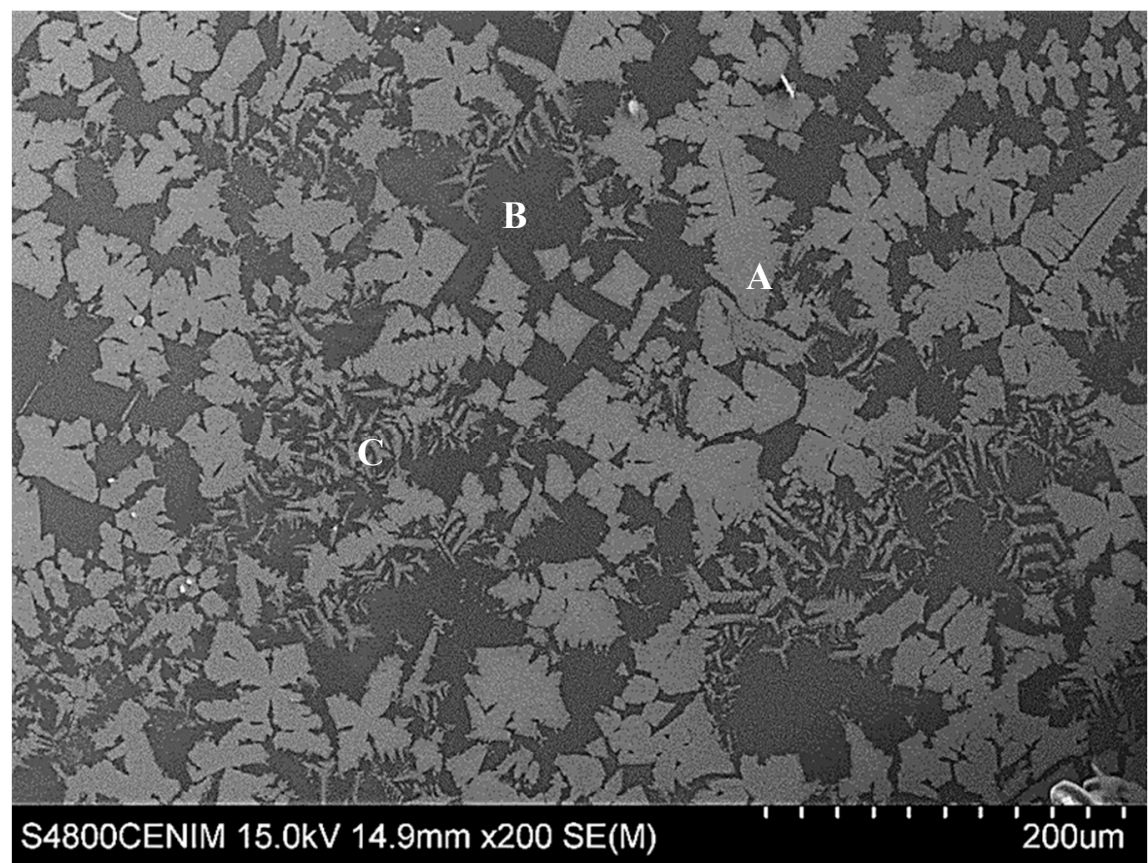

Figure 8. SEM (Scanning Electronic Microscopy) image of the slag (A) 40.7\% $\mathrm{Ta}_{2} \mathrm{O}_{5} ; 20.3 \% \mathrm{Nb}_{2} \mathrm{O}_{5}$; $16.7 \% \mathrm{CaO} ;$ (B) $4.5 \% \mathrm{Ta}_{2} \mathrm{O}_{5} ; 21.5 \% \mathrm{Nb}_{2} \mathrm{O}_{5} ; 20.5 \% \mathrm{CaO} ; 12.5 \% \mathrm{MnO}$; (C) $\mathrm{Ca}(\mathrm{Fe}, \mathrm{Mn})_{2} \mathrm{O}_{2}$.

\section{Discussion}

Carbon dioxide can be combined with carbon and transformed into carbon monoxide by the reverse-Boudouard reaction [23]. This transformation is thermodynamically favored, beginning at $700{ }^{\circ} \mathrm{C}$. As it is shown in Figure 9, the thermodynamic conditions would allow the reduction of $\mathrm{SnO}_{2}$ by carbon in standard states (applying unit value relative partial pressure of $\mathrm{CO}_{2}$ ) above approximately $700{ }^{\circ} \mathrm{C}$. The required reaction would, however, more likely occur through an indirect mechanism, with $\mathrm{CO}$ acting as the effective reducing reagent. This would be kinetically and thermodynamically more feasible and beneficial. If the $\mathrm{CO} / \mathrm{CO}_{2}$ mixture were correctly manipulated, the process would be possible at temperatures above $400{ }^{\circ} \mathrm{C}$. The reducing $\mathrm{CO}$ would be produced by the initial oxidation of the graphite particles and the subsequent Boudouard reaction. However, the latter step requires temperatures higher than $800{ }^{\circ} \mathrm{C}$ (as is commonly known). The kinetics of the reduction reaction, however, might require even higher temperatures. Mitchell and Parker [24] reduced pure stannic oxide with anthracite and graphite powder, showing the reaction to be possible in the temperature range of $700-1200{ }^{\circ} \mathrm{C}$, with the reaction rate strongly temperature-dependent. The rate of recovery is always proportional to the amount of carbon present, and the final carbon consumption corresponds to the overall reaction expressed as:

$$
\mathrm{SnO}_{2(s)}+\mathrm{C}_{(s)} \rightarrow \mathrm{Sn}_{(l)}+\mathrm{CO}_{2(g)}
$$

The main steps of the reaction can be assumed as:

$$
\begin{aligned}
& \mathrm{C}_{(s)}+\mathrm{O}_{2(g)} \rightarrow \mathrm{CO}_{2(g)} \\
& \mathrm{C}_{(s)}+\mathrm{CO}_{2(g)} \rightarrow 2 \mathrm{CO}_{(g)}
\end{aligned}
$$




$$
\begin{gathered}
\mathrm{SnO}_{2(s)}+\mathrm{CO}_{(g)} \rightarrow \mathrm{SnO}_{(s, g)}+\mathrm{CO}_{2(g)} \\
\mathrm{SnO}_{(s, g)}+\mathrm{CO}_{(g)} \rightarrow \mathrm{Sn}_{(l)}+\mathrm{CO}_{2(g)}
\end{gathered}
$$

Additionally, the thermal decomposition of $\mathrm{CaCO}_{3}$ occurs at $800{ }^{\circ} \mathrm{C}$ according to Equation (6):

$$
\mathrm{CaCO}_{3(s)} \rightarrow \mathrm{CaO}_{(s)}+\mathrm{CO}_{2(g)}
$$

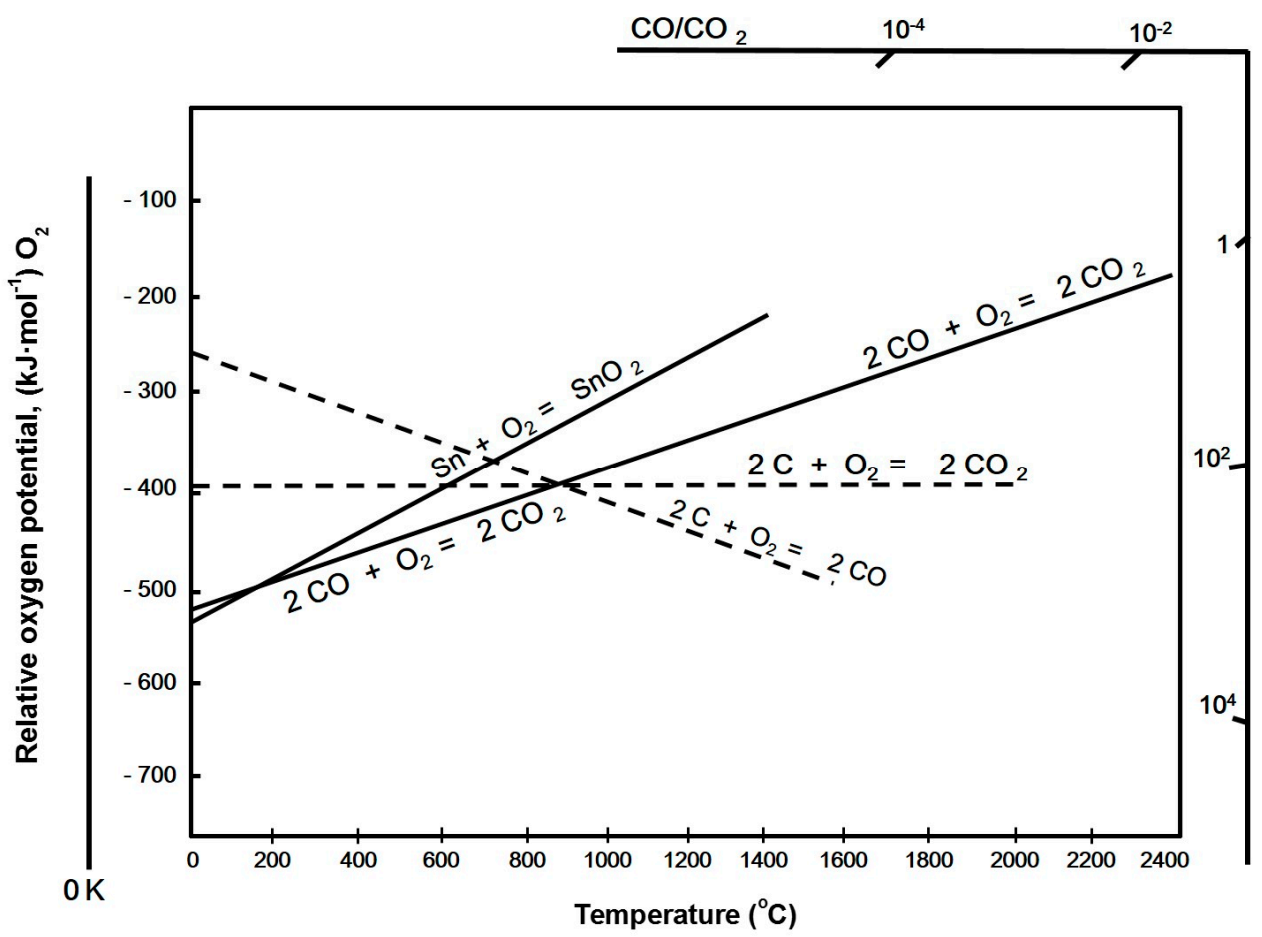

Figure 9. Ellingham diagram for tin oxide reduction.

$\mathrm{CaO}$ accelerates the reduction of cassiterite by graphite and reduces the activation energy for the reduction reaction given its catalytic effect on the Boudouard reaction [25].

In the industrial plant where the tailings were treated, minimizing the Fe content of the cassiterite is a key objective. The concentrate used in the present work had a low Fe content $(4.9 \%$, or $7 \%$ when expressed as $\mathrm{Fe}_{2} \mathrm{O}_{3}$ ). It should be noticed that $\mathrm{Fe}$ oxides have a significant effect on the reduction of the $\mathrm{Sn}$ oxides during the reduction process [26]. The equilibrium diagram for the gas phase of these $\mathrm{Fe}$ and $\mathrm{Sn}$ oxides under different $\mathrm{CO}-\mathrm{CO}_{2}$ atmospheres [27-29] indicates that the reduction of the $\mathrm{Fe}$ oxides is inevitable, and therefore that the Fe content of the raw material is $<15 \%$; were it any higher, it would affect the reduction of $\mathrm{SnO}_{2}$. In addition, any tin metal could easily combine with metallic Fe to form an alloy, and thus cause the loss of the Sn. Thus, the optimum conditions for melting the raw materials lie in the $700-1127^{\circ} \mathrm{C}$ region, with a $\mathrm{CO} /\left(\mathrm{CO}+\mathrm{CO}_{2}\right)$ ratio of $7-17 \%$ [29] in which tin oxides are reduced to tin metal but the iron oxides are reduced only to $\mathrm{FeO}$. This latter $\mathrm{FeO}$ can then combine with the $\mathrm{CaO}$ and quartz in the concentrate to form $\mathrm{Fe}-\mathrm{Ca}-\mathrm{Si}$ compounds in the slag.

The use of $\mathrm{CaCO}_{3}$ in the pyrometallurgical reduction smelting process is essential for the formation of the slag. The $\mathrm{CaO}$ formed in the decomposition of the carbonate reacts with the columbotantalite and ixiolite to form mixed oxides of $\mathrm{Ca}, \mathrm{Nb}$ and $\mathrm{Ta}$ - the majority compounds in the slag (Equation (7)), plus acicular $\mathrm{Ca}(\mathrm{Fe}, \mathrm{Mn})_{2} \mathrm{O}_{2}$ (Figure 7). However, these latter ferrites were not detected by XRD, suggesting they may actually have an amorphous nature [30].

$$
(\mathrm{Fe}, \mathrm{Mn})_{2}(\mathrm{Ta}, \mathrm{Nb})_{2} \mathrm{O}_{6}(s)+3 \mathrm{CaO}(s) \rightarrow \mathrm{Ca}_{2}(\mathrm{Nb}, \mathrm{Ta})_{2} \mathrm{O}_{7}(s)+\mathrm{Ca}(\mathrm{Fe}, \mathrm{Mn})_{2} \mathrm{O}_{2}(s)
$$


The enthalpy of formation $\left(\Delta \mathrm{H}_{\mathrm{ox}}\right)$ of $\mathrm{Ca}_{2} \mathrm{Nb}_{2} \mathrm{O}_{7}$, calculated from the binary oxides, is $-208 \mathrm{~kJ} \cdot \mathrm{mol}^{-1}$ [30]. Thus, when the enthalpy of decomposition $(\Delta \mathrm{H})$ of $\mathrm{CaCO}_{3}$ is taken into account at $298 \mathrm{~K}\left(178.8 \mathrm{~kJ} \cdot \mathrm{mol}^{-1}\right)$, the formation of the $\mathrm{Ca}_{2} \mathrm{Nb}_{2} \mathrm{O}_{7}$ becomes possible under the carbothermic reduction conditions employed. The literature contains no information on the formation of $\mathrm{Ca}_{2}(\mathrm{Nb}, \mathrm{Ta})_{2} \mathrm{O}_{7}$, but it is likely to be similar to that of $\mathrm{Ca}_{2} \mathrm{Nb}_{2} \mathrm{O}_{7}$ given the similarities of the $\mathrm{CaO}-\mathrm{Nb}_{2} \mathrm{O}_{5}$ and $\mathrm{CaO}-\mathrm{Ta}_{2} \mathrm{O}_{5}$ binary systems [31]. Finally, the formation of $\mathrm{Ca}(\mathrm{Fe}, \mathrm{Mn})_{2} \mathrm{O}_{2}$ at temperatures around $1200{ }^{\circ} \mathrm{C}$ is a well-studied phenomenon of the sintering of iron minerals, and its appearance as acicular particles has been described by Cores et al. [32].

Our group is currently designing synthesis routes for obtaining $\mathrm{Nb}$ and Ta oxides. The classical route would involve dissolving the slag in $\mathrm{HF} / \mathrm{H}_{2} \mathrm{SO}_{4}$, extraction with organic solvents, and re-extraction with ammonium salts $\left(\mathrm{NH}_{4} \mathrm{~F}\right.$ plus $\left.\mathrm{NH}_{3}\right)$. This would allow recovery of salts of the $\mathrm{K}_{2} \mathrm{Ta}_{2} \mathrm{O}_{3} \mathrm{~F}_{6}$ and $\mathrm{Nb}_{2} \mathrm{O}_{5} \cdot \mathrm{nH}_{2} \mathrm{O}$ type, from which the desired $\mathrm{Nb}$ and Ta oxides could be obtained [33].

Tin is normally deposited from divalent stannous ions, $\mathrm{Sn}^{2+}$, in an acidic $\left(\mathrm{H}_{2} \mathrm{SO}_{4}\right)$ bath [34]. At the raw, non-refined tin anode, the following oxidation reaction occurs (8):

$$
\mathrm{Sn} \rightarrow \mathrm{Sn}^{2+}+2 \mathrm{e}^{-}
$$

At the highly pure tin cathode, the following reduction reaction occurs:

$$
\mathrm{Sn}^{2+}+2 \mathrm{e}^{-} \rightarrow \mathrm{Sn}
$$

The tin cathode builds up a coating of high purity tin, extracted from the anode. Impurities of higher electrode potential than tin $(\mathrm{Fe}, \mathrm{Bi}, \mathrm{Sb}, \mathrm{As}, \mathrm{Cu}, \mathrm{Ag}, \mathrm{Au})$ mostly fail to dissolve from the anode, and build up a fine slime at its surface in their elemental or oxide form [18]. Due to uneven dissolution the anode slime also contains a significant amount of tin powder (see Table 5). This is suitable for further processing.

The theoretical quantity of metal deposited at the cathode obeys Faraday's Law, expressed as follows:

$$
m_{t}=\frac{A \cdot I \cdot t}{n \cdot F}
$$

where $m_{\exp }$ is the mass of the metal (in grams) deposited at the cathode, $A$ is the atomic mass of the metal, $I$ the current used (expressed in Amperes), $t$ the time elapsed (in seconds), $n$ the number of electrons involved in the reaction, and $F$ the Faraday constant. The resulting value for $m_{t}$ is $393.3 \mathrm{~g}$.

The efficiency of the current $(\eta, \%)$ was determined via Equation (11), comparing the mass of tin deposited at the cathode during electrolysis $\left(m_{\exp }\right)$ and the mass of tin expected $\left(m_{t}\right)$ according to Faraday's Law (Equation (10)).

$$
\eta(\%)=\frac{m_{\text {exp }}}{m_{t}} \times 100
$$

Under the reigning conditions the efficiency of the current was $93.9 \%$

The specific energy consumption ( $C E, \mathrm{kWh} / \mathrm{kg}$ ) was determined using Equation (12):

$$
C E=\frac{V_{c} \cdot I \cdot t}{1000 \cdot m_{\exp }}
$$

in which $V_{c}$ is the cell voltage (calculated as described above). Under the described conditions, and with a $V_{c}$ of $0.5 \mathrm{~V}$, the $C E$ was $0.24 \mathrm{kWh} / \mathrm{kg}$

It should be noted that the process described here could be used at other sites with tin oxides. It could also be used in the recovery of tin from metallic wastes (secondary tin) and even post-consumption wastes. It should also be remembered that today, in a world in which demand for this metal is rising, only $30 \%$ of all the tin consumed is recycled [26]. 


\section{Conclusions}

The results show that the present mining waste is a good source of cassiterite from which Sn can be obtained. When this is recovered by carbothermic reduction, the best flux to use is $\mathrm{CaCO}_{3}$. The purity of the recovered $\mathrm{Sn}$ is some $96 \%$. In addition, $90 \%$ of this $\mathrm{Sn}$ can be turned into ultra-pure $(99.97 \%)$ $\mathrm{Sn}$ via electrorefining. The slag produced in the carbothermic reduction contains $\mathrm{Ca}-\mathrm{Nb}-\mathrm{Ta}$ oxides, adding extra value to the mine tailings. Further work is underway to see how these latter elements may best be recovered from this slag.

Acknowledgments: Irene García-Díaz thanks the Ministry of Economy and Competiveness for her Postdoctoral Junior Grant (REF. FPDI-2013-16391).

Author Contributions: F.A.L. and F.G.P. conceived and designed the experiments; I.G.-D., O.R.L. and T.L. performed the experiments; F.A.L., I.G.-D. and O.R.L. analyzed the data; O.R.L. contributed reagents/materials/analysis tools; F.A.L. wrote the paper.

Conflicts of Interest: The authors declare no conflict of interest.

\section{References}

1. ITRI. 2016 Report on Global Tin Resources and Reserves. Available online: https://www.itri.co.uk/index. php?option=com_mtree\&task=att_download\&link_id=55516\&cf_id=24 (accessed on 12 January 2018).

2. Angadi, S.I.; Sreenivas, T.; Jeon, H.-S.; Baek, S.-H.; Mishra, B.K. A review of cassiterite beneficiation fundamentals and plant practices. Miner. Eng. 2015, 70, 178-200. [CrossRef]

3. Leistner, T.; Embrechts, M.; Leißner, T.; Chehreh Chelgani, S.; Osbahr, I.; Möckel, R.; Peuker, U.A.; Rudolph, M. A study of the reprocessing of fine and ultrafine cassiterite from gravity tailing residues by using various flotation techniques. Miner. Eng. 2016, 96-97, 94-98. [CrossRef]

4. Feng, Q.; Zhao, W.; Wen, S.; Cao, Q. Activation mechanism of lead ions in cassiterite flotation with salicylhydroxamic acid as collector. Sep. Purif. Technol. 2017, 178, 193-199. [CrossRef]

5. Sun, L.; Hu, Y.; Sun, W. Effect and mechanism of octanol in cassiterite flotation using benzohydroxamic acid as collector. Trans. Nonferrous Met. Soc. China (Engl. Ed.) 2016, 26, 3253-3257. [CrossRef]

6. López-Moro, F.J.; García Polonio, F.; Llorens González, T.; Sanz Contreras, J.L.; Fernández Fernández, A.; Moro Benito, M.C. Ta and Sn concentration by muscovite fractionation and degassing in a lens-like granite body: The case study of the Penouta rare-metal albite granite (NW Spain). Ore Geol. Rev. 2017, 82, 10-30. [CrossRef]

7. Johan, V.; Johan, Z. Accessory minerals of the Cínovec (Zinnwald) granite cupola, Czech Republic Part 1: $\mathrm{Nb}-$, Ta- and Ti-bearing oxides. Mineral. Petrol. 1994, 51, 323-343. [CrossRef]

8. Raimbault, L.; Cuney, M.; Azencott, C.; Duthou, J.-L.; Joron, J.L. Geochemical evidence for a multistage magmatic genesis of Ta-Sn-Li mineralization in the granite at Beauvoir, French Massif Central. Econ. Geol. 1995, 90, 548-576. [CrossRef]

9. McLellan, B.; Yamasue, E.; Tezuka, T.; Corder, G.; Golev, A.; Giurco, D. Critical Minerals and Energy-Impacts and Limitations of Moving to Unconventional Resources. Resources 2016, 5, 19. [CrossRef]

10. Llorens González, T.; García Polonio, F.; López Moro, F.J.; Fernández Fernández, A.; Sanz Contreras, J.L.; Moro Benito, M.C. Tin-tantalum-niobium mineralization in the Penouta deposit (NW Spain): Textural features and mineral chemistry to unravel the genesis and evolution of cassiterite and columbite group minerals in a peraluminous system. Ore Geol. Rev. 2017, 81, 79-95. [CrossRef]

11. Peng, Z.; Mackey, P.J. New Developments in Pyrometallurgy. JOM 2013, 65, 1550-1551. [CrossRef]

12. Zhang, Y.B.; Li, G.H.; Jiang, T.; Guo, Y.F.; Huang, Z.C. Reduction behavior of tin-bearing iron concentrate pellets using diverse coals as reducers. Int. J. Miner. Process. 2012, 110-111, 109-116. [CrossRef]

13. Ha, H.; Yoo, M.; An, H.; Shin, K.; Han, T.; Sohn, Y.; Kim, S.; Lee, S.-R.; Han, J.H.; Kim, H.Y. Design of Reduction Process of $\mathrm{SnO}_{2}$ by $\mathrm{CH}_{4}$ for Efficient $\mathrm{Sn}$ Recovery. Sci. Rep. 2017, 7, 14427. [CrossRef] [PubMed]

14. Komkov, V.G.; Gostishchev, V.V.; Ri, E.K. Physicochemical aspects of carbothermic reduction of cassiterite in the ionic melt. Russ. J. Non-Ferrous Met. 2009, 50, 596-599. [CrossRef]

15. You, Z.; Li, G.; Wen, P.; Peng, Z.; Zhang, Y.; Jiang, T. Reduction of Sn-Bearing Iron Concentrate with Mixed $\mathrm{H}_{2} / \mathrm{CO}$ Gas for Preparation of Sn-Enriched Direct Reduced Iron. Metall. Mater. Trans. B 2017, 48, 1486-1493. [CrossRef] 
16. Van Deventer, J.S.J. The effect of admixtures on the reduction of cassiterite by graphite. Thermochim. Acta 1988, 124, 109-118. [CrossRef]

17. Cetinkaya, S.; Eroglu, S. Thermodynamic analysis and reduction of tin oxide with methane. Int. J. Miner. Process. 2012, 110, 71-73. [CrossRef]

18. Rimaszeki, G.; Kulcsar, T.; Kekesi, T. Application of $\mathrm{HCl}$ solutions for recovering the high purity metal from tin scrap by electrorefining. Hydrometallurgy 2012, 125-126, 55-63. [CrossRef]

19. Rimaszeki, G.; Kulcsar, T.; Kekesi, T. Investigation and optimization of tin electrorefining in hydrochloric acid solutions. J. Appl. Electrochem. 2012, 42, 573-584. [CrossRef]

20. Kekesi, T. Electrorefining in aqueous chloride media for recovering tin from waste materials. Acta Metall. Slovaca 2013, 19, 196-205. [CrossRef]

21. López, F.A.; Alguacil, F. Recovery of high-purity $\mathrm{Sn}$ from $\mathrm{Sn}$ alloys containing $\mathrm{Pb}$ by means of electro refining. Patent WO 2016/075350-A1, 19 May 2016.

22. Deposita, M. Magnetism in Cassiterite. Miner. Depos. 1966, 171, 148-171. [CrossRef]

23. Nagase, K.; Shimodaira, T.; Itoh, M.; Zheng, Y. Kinetics and mechanisms of the reverse Boudouard reaction over metal carbonates in connection with the reactions of solid carbon with the metal carbonates. Phys. Chem. Chem. Phys. 1999, 1, 5659-5664. [CrossRef]

24. Mitchell, A.R.; Parker, R.H. The reduction of $\mathrm{SnO}_{2}$ and $\mathrm{Fe}_{2} \mathrm{O}_{3}$ by solid carbon. Miner. Eng. 1988, 1, 53-66. [CrossRef]

25. Padilla, R.; Sohn, H.Y. The reduction of stannic oxide with carbon. Metall. Trans. B 1979, 10, 109-115. [CrossRef]

26. Su, Z.; Zhang, Y.; Liu, B.; Lu, M.; Li, G.; Jiang, T. Extraction and Separation of Tin from Tin-Bearing Secondary Resources: A Review. JOM 2017, 69, 2364-2372. [CrossRef]

27. Zhang, Y.B. Research on Physicochemical Fundamental and New Technology of Tin, Zinc-Bearing Complex Iron Concentrate Pellets by Weak Reduction Roasting. Ph.D. Thesis, Central South University, Changsha, China, 2006.

28. Su, Z.; Zhang, Y.; Chen, J.; Liu, B.; Li, G.; Jiang, T. Selective separation and recovery of iron and tin from high calcium type tin- and iron-bearing tailings using magnetizing roasting followed by magnetic separation. Sep. Sci. Technol. 2016, 51, 1900-1912. [CrossRef]

29. Li, G.; You, Z.; Zhang, Y.; Rao, M.; Wen, P.; Guo, Y.; Jiang, T. Synchronous Volatilization of Sn, Zn, and As, and Preparation of Direct Reduction Iron (DRI) from a Complex Iron Concentrate via CO Reduction. JOM 2014, 66, 1701-1710. [CrossRef]

30. Leitner, J.; Nevřiva, M.; Sedmidubský, D.; Voňka, P. Enthalpy of formation of selected mixed oxides in a CaO-SrO-Bi2O3-Nb2O5 system. J. Alloys Compd. 2011, 509, 4940-4943. [CrossRef]

31. Ibrahim, M.; Bright, N.F.H.; Rowland, J.F. The Binary System CaO-Nb2O5. J. Am. Ceram. Soc. 1962, 45, 329-334. [CrossRef]

32. Cores, A.; Mochón, J.; Ruiz-Bustinza, I.; Parra, R. Control of the flame front advance in a sintering bed of iron ores. Rev. Metal. 2010, 46, 249-259. [CrossRef]

33. Nete, M.; Purcell, W.; Nel, J.T. Hydrometallurgical Separation of Niobium and Tantalum: A Fundamental Approach. JOM 2016, 68, 556-566. [CrossRef]

34. Walsh, F.C.; Low, C.T.J. A review of developments in the electrodeposition of tin. Surf. Coat. Technol. 2016, 288, 79-94. [CrossRef]

(C) 2018 by the authors. Licensee MDPI, Basel, Switzerland. This article is an open access article distributed under the terms and conditions of the Creative Commons Attribution (CC BY) license (http:/ / creativecommons.org/licenses/by/4.0/). 